\title{
PENGENALAN MEDIA PEMBELAJARAN TAJWID BERBASIS FLASH DI SMP HIKMAH TELADAN CIMAHI
}

\author{
Agus Taufik Rahman \\ Mahasiswa Pasca Sarjana Universitas Islam Negeri Sunan Gunung Djati Bandung \\ Jl. Soekarno Hatta, Cipadung, Bandung, Jawa Barat \\ Email: a_taufik_r@yahoo.com
}

\author{
Ari Kaharudin Shaleh \\ Mahasiswa Pasca Sarjana Universitas Islam Negeri Sunan Gunung Djati Bandung \\ Jl. Soekarno Hatta, Cipadung, Bandung, Jawa Barat \\ Email: Arieshaleh@gmail.com
}

\author{
Abdul Qodir \\ Mahasiswa Pasca Sarjana Universitas Islam Negeri Sunan Gunung Djati Bandung \\ Jl. Soekarno Hatta, Cipadung, Bandung, Jawa Barat \\ Email:
}

\begin{abstract}
Learning media used is very determine the success of the delivery of materials, both in the school environment, religious education institutions and also home learning .. It is necessary to support these activities in the form of innovations in learning methods. Computer technology can be used to support such activities as a software development facility in the learning model, The use of learning media is needed to overcome the problems that arise in the learning process tajwid. For that reason developed a computerized learning media applications. Submission of learning with computerized applications can help the learning process so as not monotonous because accompanied by animation and audio. The method used in this research is literature study - includes study on similar research and study of supporting literature, observation process (observation) on Tajwid learning process process. And the system development using waterfall model. The result of this research is Flash-based Tajwid learning media software.
\end{abstract}

Keyword:

Design, Waterfall, Media, Learning

\begin{abstract}
Abstrak : Media pembelajaran yang digunakan sangat menetukan keberhasilan penyampaian materi, baik dilingkungan sekolah, instansi - instansi pendidikan agama dan juga pembelajaran di rumah.. Hal yang diperlukan untuk menunjang kegiatan tersebut yaitu berupa inovasi - inovasi dalam metode pembelajaran. Teknologi komputer dapat digunakan untuk menunjang kegiatan tersebut yaitu sebagai fasilitas pengembangan suatu perangkat lunak dalam model pembelajaran, Penggunaan media pembelajaran dibutuhkan untuk mengatasi permasalahan yang muncul dalam proses pembelajaran tajwid. Untuk itulah dikembangkan sebuah aplikasi media pembelajaran yang terkomputerisasi. Penyampaian pembelajaran dengan aplikasi yang terkomputerisasi dapat membantu proses pembelajaran agar tidak monoton karena disertai dengan animasi dan audio. Metode yang digunakan dalam penelitian ini adalah studi kepustakaanmencakup kajian terhadap penelitian sejenis dan studi terhadap literatur yang mendukung, proses observasi (pengamatan) terhadap proses kegiatan pembelajaran Tajwid. Dan pengembangan sistemnya memakai model waterfall. Hasil dari penelitian ini adalah berupa software media pembelajaran Tajwid berbasis Flash.
\end{abstract}

Kata Kunci: 
Design, Waterfall, Media, Pembelajaran

\section{PENDAHULUAN}

Dewasa ini para pengajar atau guru terutama guru PAI dihadapkan dengan tantangan bagaimana cara mengajar dengan baik dan bisa diterima baik oleh para muridnya. Tentu saja ini bukan tantangan ringan, karena tiap pengajar dari tiap daerah mempunyai kelebihan dan kekurangan dari berbagai aspek pendidikan, entah itu fasilitasnya, jenis muridnya, dan lain-lain. Pengajar juga harus mempunyai strategi yang jitu untuk setidaknya membuat pengajaran menjadi mudah dan bisa diterima oleh siswa, karena sulit membuat pengajaran bisa diterima oleh semua siswa. Perkembangan teknologi informasi terjadi pada berbagai bidang, baik perangkat lunak maupun perangkat keras khususnya pada bidang multimedia. Perkembangan tersebut salah satunya yaitu pada bidang pendidikan. Pada proses pembelajaran dalam dunia pendidikan, komputer telah dilibatkan sebagai sarana pembelajaran Komputer merupakan salah satu teknologi informasi yang telah banyak digunakan untuk mempermudah kehidupan manusia saat ini. Pada dunia pendidikan seorang guru dituntut untuk menyelenggarakan pembelajaran yang bermakna dan menyenangkan dengan menggunakan berbagai metode dan media yang menarik dalam pembelajaran dengan harapan siswa tidak merasa terbebani dengan banyaknya materi yang harus mereka hafalkan dan siswa merasa terus tertarik dengan materi yang disampaikan oleh guru. Untuk dapat mewujudkan hal tersebut maka salah satunya adalah dengan menyelenggarakan pembelajaran menggunakan media pembelajaran interaktif. Melihat kondisi dilapangan bahwa media pembelajaran dapat memudahkan para siswa untuk lebih memahami pembelajaran sesuai dengan tujuan pembelajaran yang hendak dicapai maka pembelajaran berbasis teknologi perlu untuk diterapkan. Melihat kenyataan tersebut maka Pengenalan Media Pembelajaran Interaktif ini dipandang sebagai salah satu pemecahannya.

\section{METODOLOGI PENELITIAN}

Pressman, Roger. S (1997) Waterfall model adalah model klasik yang bersifat sistematis, berurutan dalam membangun software. Selain itu Model ini merupakan model yang paling banyak dipakai oleh para pengembang software. Inti dari metode waterfall adalah pengerjaan dari suatu sistem yang dilakukan secara berurutan atau secara linear. Jadi jika langkah satu belum dikerjakan maka tidak akan bisa melakukan pengerjaan langkah 2, 3 dan seterusnya. Secara otomatis tahapan ke-3 akan bisa dilakukan jika tahap ke-1 dan ke-2 sudah dilakukan. Berikut ini adalah gambaran dari waterfall model: 


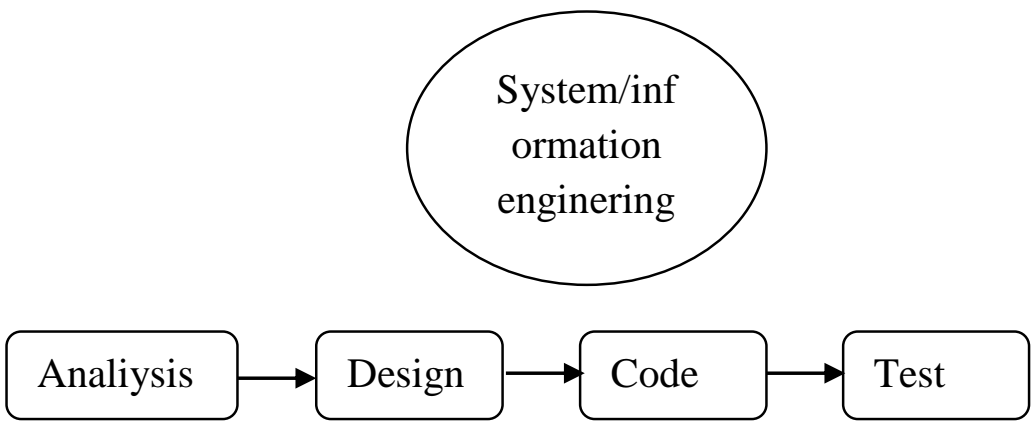

Langkah awal yang dilakukan dalam Waterfall Model yaitu menganalisis terlebih dahulu. Ketika teori gambar di atas menggambarkan menganalisis untuk membangun software. Tahapan - tahapan yang ada pada model waterfall secara global adalah:

1. Analisis Kebutuhan

Tahap analisis kebutuhan adalah proses pengumpulan kebutuhan yang dilakukan secara intensif untuk mespesifikasikan kebutuhan perangkat lunak agar dapat dipahami seperti apa yang dibutuhkan oleh user.

\section{Desain}

Tahap desain (design) yaitu proses multi langkah yang fokus pada desain pembuatan program perangkat lunak termasuk strutur data, arsitektur perangkat lunak, representasi antar muka dan prosedur pengodean.

\section{Code Generation}

Tahap code generation adalah desain harus ditranslasikan ke dalam program perangkat lunak". Hasil dari tahap ini adalah program komputer sesuai dengan desain yang telah dibuat pada tahap desain.

\section{Pengujian}

Tahap pengujian (testing) adalah fokus pada perangkat lunak secara dari segi lojik dan fungsional dan memastikan bahwa semua bagian sudah diuji.

\section{TEMUAN DAN PEMBAHASAN}

Multimedia adalah "penggunaan komputer untuk menyajikan dan menggabungkan teks, suara, gambar, animasi dan video dengan alat bantu (tool) dan koneksi (link) sehingga pengguna dapat bernavigasi, berinteraksi, berkarya dan berkomunikasi" Hofstetter (2001) mengatakan bahwa komponen multimedia terbagi atas lima jenis yaitu:

1. Teks. Teks merupakan elemen multimedia yang menjadi dasar untuk menyampaikan informasi, karena teks adalah jenis data yang paling sederhana dan membutuhkan tempat penyimpanan yang paling kecil. Teks merupakan cara yang paling efektif dalam mengemukakan ide-ide kepada pengguna, sehingga penyampaian informasi akan lebih mudah dimengerti oleh masyarakat.

2. Grafik (image). Sangat bermanfaat untuk mengilustrasikan informasi yang akan disampaikan terutama informasi yang tidak dapat dijelaskan dengan kata-kata. Jenis-jenis grafik seperti bitmap yaitu gambar yang disimpan dalam bentuk kumpulan pixel, yang berkaitan dengan titik-titik pada layar monitor. Digitized picture adalah gambar hasil rekaman video atau kamera yang dipindahkan ke 
komputer dan diubah kedalam bentuk bitmaps. Hyper pictures, sama seperti hypertext hanya saja dalam bentuk gambar.

3. Audio Multimedia tidak akan lengkap jika tanpa audio (suara). Audio bisa berupa percakapan, musik atau efek suara. Format dasar audio terdiri dari beberapa jenis :WAVE Merupakan format file digital audio yang disimpan dalam bentuk digital dengan eksistensi WAV. MIDI (Musical Instrument Digital Interface) MIDI memberikan cara yang lebih efisien dalam merekam musik dibandingkan wave, kapasitas data yang dihasilkan juga jauh lebih kecil. MIDI disimpan dalam bentuk MID. Video,Video menyediakan sumber yang kaya dan hidup untuk aplikasi multimedia. Dengan video dapat menerangkan hal-hal yang sulit digambarkan lewat kata-kata atau gambar diam dan dapat menggambarkan emosi dan psikologi manusia secara lebih jelas. Animasi. Animasi adalah simulasi gerakan yang dihasilkan dengan menayangkan rentetan frame ke layer. Frame adalah satu gambar tunggal pada rentetan gambar yang membentuk animasi

Multimedia merupakan bagian dari sistem pendidikan. Sistem dapat diartikan sebagai suatu kesatuan integral dari sejumlah komponen. Komponen-komponen tersebut satusama lain saling berpengaruh dengan fungsinya masing-masing, tetapi secara fungsi komponen itu, terarah pada pencapaian satu tujuan (yaitu tujuan dari sistem itu sendiri). sistem bermanfaat untuk merancang / merencanakan suatu proses pembelajaran. Perencanaan adalah proses dan cara berpikir yang dapat membantu menciptakan hasil yang diharapkan.

Pola pendekatan sistem pembelajaran, menurut Oemar Hamalik Omar Hamalik (2002:8-9) melalui langkah-langkah sebagai berikut:

1. Identifikasi kebutuhan pendidikan (merumuskan masalah);

2. Analisis kebutuhan untuk mentransfomasikan menjadi tujuan pembelajaran (analisis masalah);

3. Merancang metode dan materi pembelajaran (pengembangan suatu pemecahan);

4. Pelaksanaan pembelajaran (eksperimental); dan

5. Menilai dan merevisi.

Sistem pembelajaran adalah hubungan antar unsur-unsur yang saling berhubungan untuk mencapai tujuan dari pembelajaran. Unsur-unsur dalam pembelajaran yaitu; manusiawi, material, fasilitas, perlengkapan, dan prosedur. Oleh sebab itu proses perencanaan yang sistematis dalam proses pembelajaran mempunyai beberapa keuntungan diantaranya sebagai berikut:

1. Melalui sistem perencanaan yang matang guru akan terhindar dari keberhasilan secara untung-untungan. Sistem memiliki peran yang kuat dalam keberhasilan suatu proses pembelajaran karena memang perencanaan disusun untuk mencapai hasil yang optimal.

2. Melalui sistem perencanaan yang sistematis, setiap guru dapat menggambarkan berbagai hambatan yang mungkin akan dihadapi. Sehingga dapat menentukan berbagai strategi yang bisa dilakukan untuk mencapai tujuan yang diharapkan. 
3. Melalui sistem perencanaan, guru dapat menentukan berbagai langkah dalam memanfaatkan berbagai sumber dan fasilitas yang ada untuk ketercapaian tujuan. Wina Sanjaya (2008:51)

Multimedia merupakan bagian dari media Pembelajaran. Sadiman (1996:51) memberikan pengertian media pembelajaran adalah paduan antara bahan dan alat atau perpaduan antara software dan hardware. Media pembelajaran bisa dipahami sebagai media yang digunakan dalam proses dan tujuan pembelajaran. Pada hakikatnya proses pembelajaran juga merupakan komunikasi, maka media pembelajaran bisa dipahami sebagai media komunikasi yang digunakan dalam proses komunikasi tersebut, media pembelajaran memiliki peranan penting sebagai sarana untuk menyalurkan pesan pembelajaran.

AECT (Association of Education and Communication Technology) memberi batasan tentang media sebagai segala bentuk dan saluran yang digunakan untuk menyampaikan pesan atau informasi. Disamping sebagai sistem penyampai atau pengantar, media yang sering diganti dengan kata mediator, dengan istilah mediator media menunjukkan fungsi atau perannya, yaitu mengatur hubungan yang efektif antara dua pihak utama dalam proses belajar, yaitu siswa dan isi pelajaran. Ringkasnya, media adalah alat yang menyampaikan atau mengantarkan pesan-pesan pengajaran (Arsyad, Azhar, 2011:3).

Menurut Anderson (1987) yang dikutip Bambang Warsita (2008:123) media dapat dibagai dalam dua kategori, yaitu alat bantu pembelajaran (instructional aids) dan media pembelajaran (instructional media). Alat bantu pembelajaran atau alat untuk membantu guru (pendidik) dalam memperjelas materi (pesan) yang akan disampaikan. Oleh karena itu alat bantu pembelajaran disebut juga alat bantu mengajar (teaching aids). Misalnya OHP/OHT, film bingkai (slide) foto, peta, poster, grafik, flip chart, model benda sebenarnya dan sampai kepada lingkungan belajar yang dimanfaatkan untuk memperjelas materi pembelajaran.

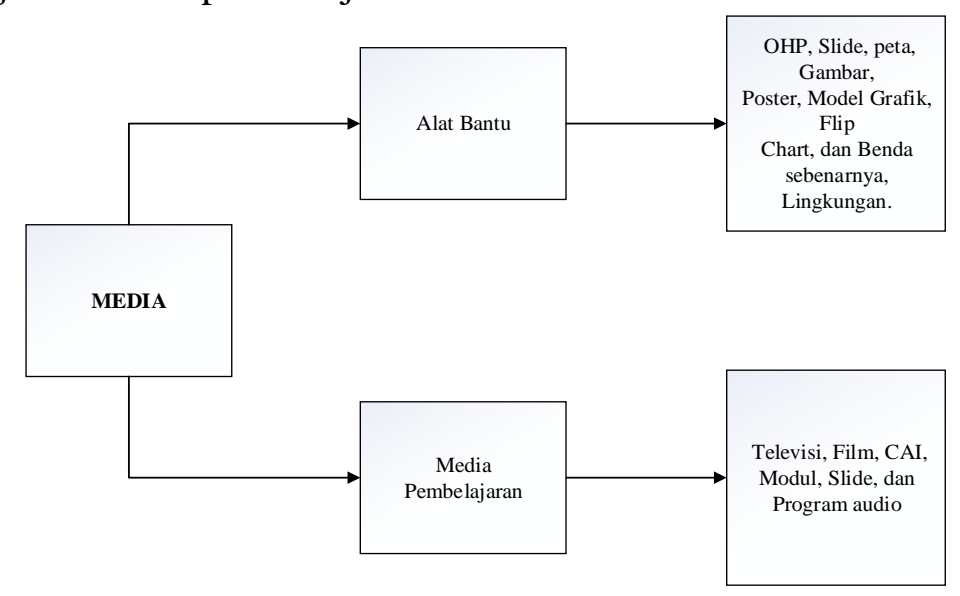

Gambar 1. Bagan Penggolongan Media

Nana Sudjana dan Ahmad Rivai (2002:2), mengemukakan beberapa manfaat media pembelajaran dalam proses belajar siswa yaitu:

1. Pembelajaran akan lebih menarik perhatian siswa sehingga dapat menumbuhkan 
motivasi belajar.

2. Bahan pembelajaran akan lebih jelas maknanya sehingga dapat lebih dipahami oleh siswa sehingga memungkinkannya menguasai dan mencapai tujuan pembelajaran.

3. Metode mengajar akan lebih bervariasi, tidak semata-mata komunikasi verbal melalui penuturan kata-kata oleh guru, sehingga siswa tidak bosan dan guru tidak kehabisan tenaga, apalagi bila guru mengajar pada setiap jam pelajaran.

4. Siswa dapat lebih banyak melakukan kegiatan belajar sebab tidak hanya mendengarkan uraian guru, tetapi juga aktivitas lain seperti mengamati, melakukan mendemonstrasikan, memamerkan, dll.

Sebagai guru dalam lingkungan mengajar di kelas akan lebih bervariasi menggunakan media, tidak semata-mata komunikasi verbal melalui penuturan kata- kata oleh guru, sehingga siswa tidak bosan dan guru tidak kehabisan tenaga, apalagi bila guru mengajar untuk setiap jam pelajaran siswa lebih banyak melakukan kegiatan belajar, sebab tidak hanya mendengarkan uraian guru, tetapi juga aktifitas lain seperti mengamati, melakukan, mendemonstrasikan dan lain-lain.

\section{Macromedia Flash 8}

Macromedia Flash 8 adalah salah suatu program yang dapat digunakan untuk membuat suatu karya animasi, tidak sedikit para animator membuat beragam animasi, seperti animasi interaktif maupun non interaktif. Menurut Ariesto Hadi Sutopo (2003:1) "Macromedia Flash 8 adalah standar professional untuk pembuatan animasi web, memiliki kemampuan pengelolaan grafis, audio, dan video dan mampu mengakomodasi semuanya dalam suatu animasi yang disebut movie." Pemanfaatan Macromedia Flash 8 dapat membantu dalam membuat animasi kartun, web design, presentasi, portofolio instansi, game, dan beberapa media animasi lainnya. Saat ini banyak versi animasi flash yaitu Adobe Flash CS4 \& CS5, semakin bertambahnya versi dalam suatu program aplikasi, akan terdapat suatu perubahan dalam program tersebut baik dari segi tata letak tools, penambahan fitur yang lebih lengkap.

Salah satu menu dari Macromedia Flash 8 adalah adanya action script. Action Script adalah bahasa pemrograman action pada flash, jenis script yang dipakai serupa dengan bahasa pemograman Java, oleh karena itu kebanyakan orang yang telah ahli java atau setidaknya kenal tidak akan kesulitan mengintegrasikan pada Flash, untuk terciptanya sebuah animasi dengan action yang sangat bermanfaat dalam Internet Communication yang lebih atraktif dan lebih efisien. Penggunaan action script di Macromedia Flash 8 untuk pelajaran akuntansi dapat menyuguhkan bentuk visual yang menarik. Materi pelajaran yang diberikan lebih menyenangkan, karena pembuat materi dapat men-setting materi yang akan diajarkan secara kreatif.

Dalam rekayasa perangkat lunak, terdapat suatu pendekatan yang disebut waterfall model. Model ini merupakan model yang paling banyak dipakai oleh para pengembang software. Awal mula Waterfall model digunakan dalam membangun sofware, sebelum dijadikan salah satu desain model pembelajaran di sekolah. Waterfall Model adalah model klasik yang bersifat sistematis, berurutan dalam membangun 
software. Nama model ini sebenarnya adalah "Linear Sequential Model”. Model ini sering disebut dengan "classic life cycle" atau model waterfall. Model ini adalah model yang muncul pertama kali yaitu sekitar tahun 1970 sehingga sering dianggap kuno, tetapi merupakan model yang paling banyak dipakai didalam Software Engineering (SE).

Model ini melakukan pendekatan secara sistematis dan urut mulai dari level kebutuhan sistem lalu menuju ke tahap analisis, desain, coding, testing/ verification, dan maintenance. Disebut dengan waterfall karena tahap demi tahap yang dilalui harus menunggu selesainya tahap sebelumnya dan berjalan berurutan. Sebagai contoh tahap desain harus menunggu selesainya tahap sebelumnya yaitu tahap requirement.

Selanjutnya akan kita kaji fase-fase dalam Waterfall Model menurut Sommerville (2011: 30-31) sebagai berikut.

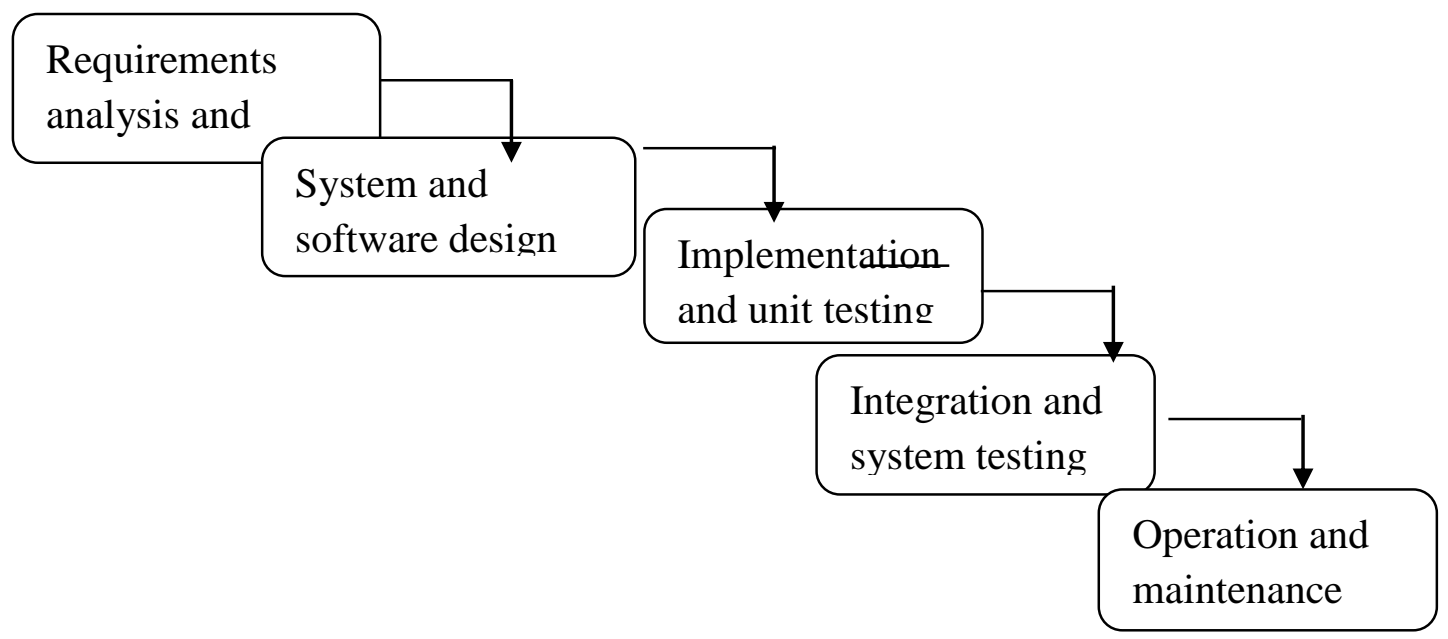

Berdasarkan gambar fase-fase dalam Waterfall Model menurut Sommerville dapat dijelaskan sebagai berikut.

1. Requirements analysis and definition ialah mengumpulkan kebutuhan secara lengkap kemudian kemudian dianalisis dan didefinisikan kebutuhan yang harus dipenuhi oleh program yang akan dibangun. Fase ini harus dikerjakan secara lengkap untuk bisa menghasilkan desain yang lengkap.

2. System and software design yaitu desain dikerjakan setelah kebutuhan selesai dikumpulkan secara lengkap. Tahap ini dilakukan sebelum melakukan coding. Tahap ini bertujuan untuk memberikan gambaran apa yang seharusnya dikerjakan dan bagaimana tampilannya. Tahap ini membantu dalam menspesifikasikan kebutuhan hardware dan sistem serta mendefinisikan arsitektur sistem secara keseluruhan.( Sommerville:30-31)

3. Implementation and unit testing ialah desain program diterjemahkan ke dalam kode-kode dengan menggunakan bahasa pemrograman yang sudah ditentukan. Program yang dibangun langsung diuji baik secara unit. Dalam tahap ini dilakukan pemrograman. Pembuatan software dipecah menjadi modul-modul kecil yang nantinya akan digabungkan dalam tahap berikutnya. Selain itu dalam 
tahap ini juga dilakukan pemeriksaaan terhadap modul yang dibuat, apakah sudah memenuhi fungsi yang diinginkan atau belum.

4. Integration and system testing yaitu penyatuan unit-unit program kemudian diuji secara keseluruhan (system testing. Di tahap ini dilakukan penggabungan modulmodul yang sudah dibuat dan dilakukan pengujian ini dilakukan untuk mengetahui apakah software yang dibuat telah sesuai dengan desainnya dan masih terdapat kesalahan atau tidak.

5. Operation and maintenance yaitu mengoperasikan program dilingkungannya dan melakukan pemeliharaan, seperti penyesuaian atau perubahan karena adaptasi dengan situasi sebenarnya. Ini merupakan tahap terakhir dalam model waterfall. Software yang sudah jadi dijalankan serta dilakukan pemeliharaan. Pemeliharaan termasuk dalam memperbaiki kesalahan yang tidak ditemukan pada langkah sebelumnya. Perbaikan implementasi unit sistem dan peningkatan jasa sistem sebagai kebutuhan baru. (Justinus,2007).

\section{HASIL DAN PEMBAHASAN}

Multimedia pengenalan Tajwid ini dibuat untuk meningkatkan semangat dan daya ingat peserta didik dalam memahami kaidah tajwid. Dalam konsep ini beberapa bahan materi yang akan ditampilkan diintegrasikan dalam sebuah program dalam bentuk tampilan audio visual, agar lebih menarik dan meningkatkan semangat belajar. Dengan Memanfaatkan media ini diharapkan proses belajar mengajar dapat berjalan lebih praktis dan efisien. Menurut Simamora (2009:66) Fungsi media adalah:

1. Memperjelas pesan agar tidak terlalu verbalitas.

2. Mengatasi keterbatasan ruang, waktu tenaga, dan daya indra.

3. Menimbulkan semangat belajar, interaksi langsung antara peserta didik dan sumber belajar.

4. Memungkinkan peserta belajar mandiri dengan bakat dan,kemampuan visual serta kinestetiknya.

5. Memeberikan stimulasi yang sama, membandingkan pengalaman, dan menimbulkan persepsi yang sama.

\section{Konsep Pembelajaran Multimedia Pengenalan Tajwid}

Multimedia digunakan sebagai sanana untuk memudahkan dalam kegiatan belajar mengajar, pengunaan media ini sangat di butuhkan agar ilmu yang disampaikan dapat terserap dan di terima dengan mudah oleh peserta didik. Syarat media pembelajaran yang baik Adalah:

1. Media pembelajaran harus meningkatkan motivasi peserta didik.

2. Menstimulus peserta didik mengingat apa yang sudah di pelajari Selalu memberikan stimulasi belajar baru.

3. Menstimulasi Peserta didik dalam memberikan tanggapan umpan balik, dan juga mendorong mereka untuk melakukan praktik dengan benar. 
Kriteria untuk menilai multimedia interaktif adalah sebagai berikut:

1. Kemudahan Navigasi. Sebuah program harus dirancang sesederhana mungkin Sehingga peserta didik yang sedang mempelajari bahasa tidak perlu Belajar komputer dahulu.

2. Kognisi, Pengetahuan, dan Penyajian (presentasi) informasi. Kriteria ini untuk menilai isi program, apakah program telah memenuhi kebutuhan pembelajaran peserta didik atau belum.

3. Integrasi Media. Media harus Mengintegrasi aspek dan keterapilan bahasa yang harus di pelajari

4. Estetika. Untuk Menarik Pinat Peserta didik program harus mempunyai tampilan yang artistik.

5. Fungsi keseluruhan. Program yang dikembangkan harus memberikan pembelajaran yang diinginkan oleh peserta didik sehingga saat peserta didik selesai

menjalankan sebuah program mereka telah belajar sesuatu.

\section{Konsep Penggunaan Waterfall}

Waterfall model adalah model klasik yang bersifat sistematis, berurutan dalam membangun software. Pada kegiatan ini yang diusulkan adalah sebagai berikut:

1. Analisa kebutuhan (Requirements analysis and definition) Mengumpulkan kebutuhan secara lengkap kemudian dianalisis dan didefinisikan kebutuhan yang harus dipenuhi oleh program yang akan dibangun. Fase ini harus dikerjakan secara lengkap untuk dapat menghasilkan desain yang lengkap. (pada kegiatan ini proses dilakukan dengan menganalisa kebutuhan apa saja yang ada pada kegiatan belajar SMP Hikmah Teladan khususnya dalam mata pelajaran Quran Hadits

2. Design sistem dan perangkat lunak (System and software design).Desain dikerjakan setelah kebutuhan selesai dikumpulkan secara lengkap. (pada kegiatan ini desain sistem dibuat dengan menganalisa kebutuhan sistem dan software yang ada dengan menggunakan Macromedia Flash 8).

3. Penulisan kode Program (Implementation and unit testing). Desain program diterjemahkan ke dalam kode-kode dengan menggunakan bahasa pemrograman yang sudah ditentukan. Program yang dibangun langsung diuji. (pada kegiatan ini merancang penulisan kode program seperti animasi, audio, gambar dll).

4. Penerapan dan Pengujian (Integration and system testing). Penyatuan unit-unit program kemudian diuji secara keseluruhan (system testing)

5. Pemeliharaan (Operation and maintenance). Mengoperasikan program dilingkungannya dan melakukan pemeliharaan, seperti penyesuaian atau perubahan karena adaptasi dengan situasi sebenarnya. Tahap Tahap dalam pelaksanaan model waterfall dapat dilihat di bawah ini : 


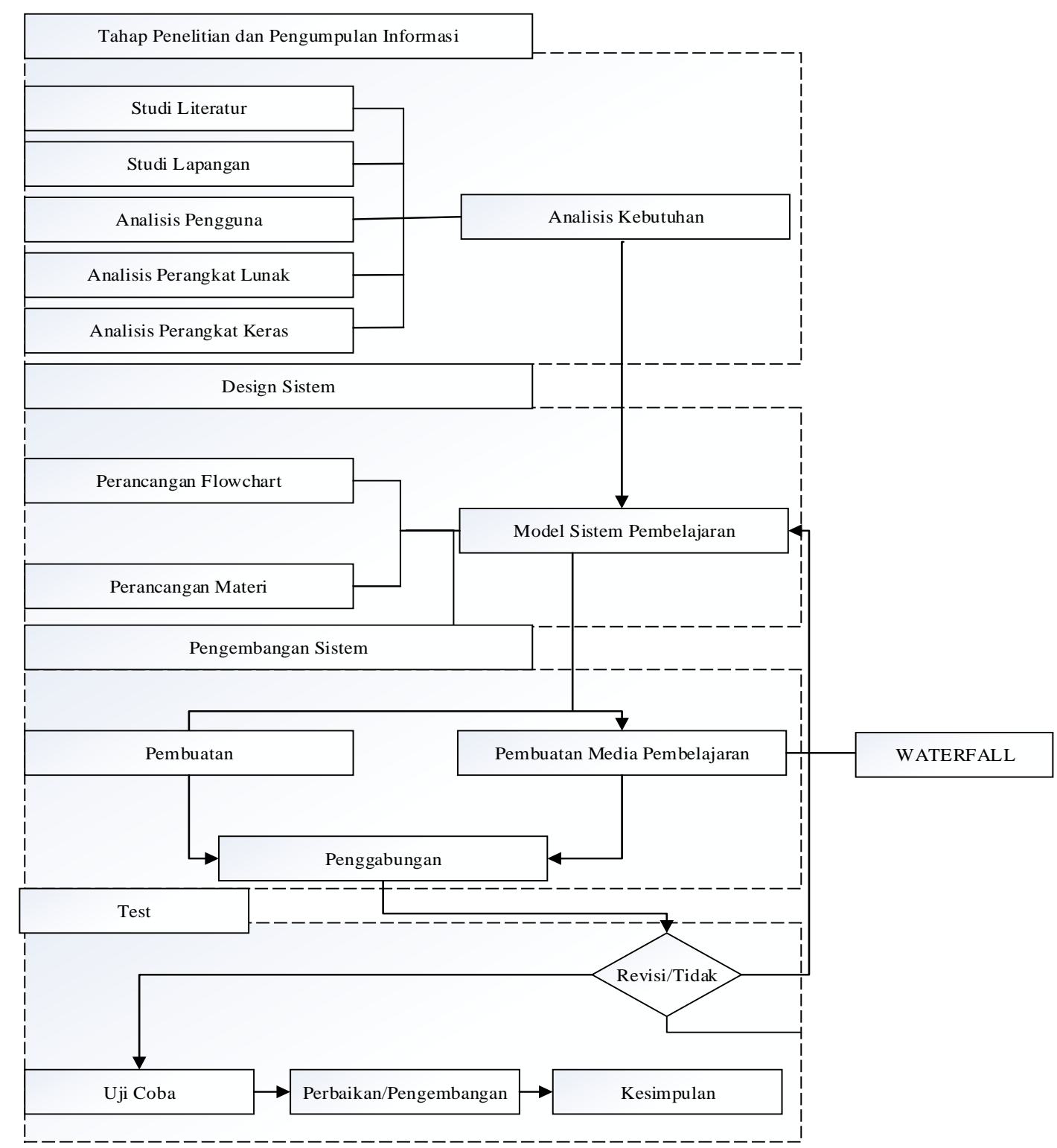

\section{Rancangan dalam Penerapan Model Waterfall \\ Kebutuhan Sistem}

Kebutuhan untuk menjalankan sistem dibagi menjadi dua bagian yaitu kebutuhan perangkat keras dan kebutuhan perangkat lunak. Implementasi perangkat keras yang digunakan dalam merancang visualisasi pembelajaran tajwid dalam membaca Alqur'an berbasis multimedia ini kebutuhan minimal dalam menjalankan software adalah :

1. Processor intel Celeron, $1.80 \mathrm{GHz}$.

2. Random Acces Memory (RAM) $256 \mathrm{MB}$.

3. Harddisk 80 GB.

4. Keyboard dan mouse

\section{Rancangan Halaman Utama}


Gambar 1.1

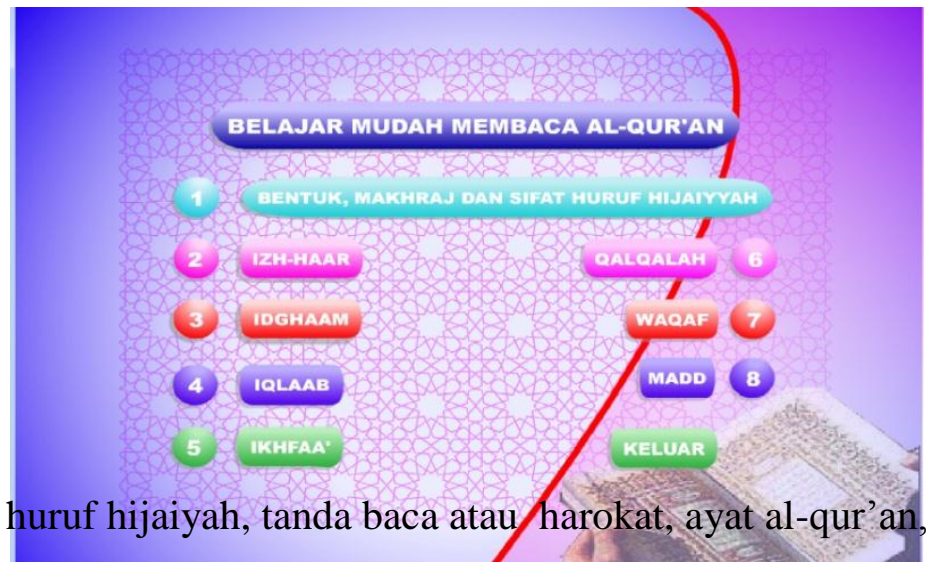

Berikut disamping kiri adalah gambaran

sistem menggunakan macromedia flash 8, halaman awal pengenalan tajwid berbasis flash dimana terdapat pilihan pilihan hukum tajwid didalamnya. Materi - materi yang disampaikan antara lain

\section{Rancangan Halaman Berbagai contoh Ilmu Tajwid Sesuai Pilihan}

\section{Gambar 1.2}

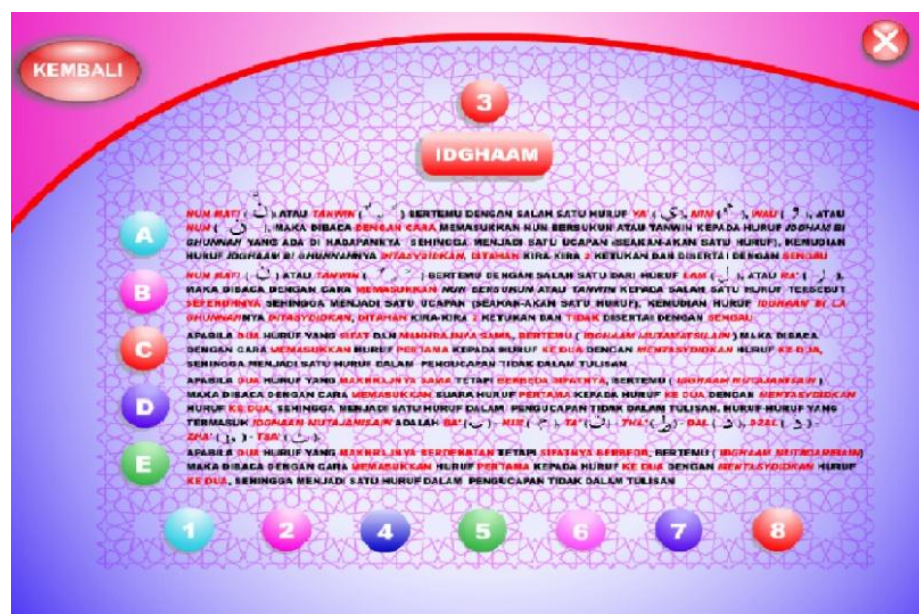

Berikut gambaran contoh dan ciri ciri ilmu tajwid sesuai pilihan yang ditentukan, disamping adalah contoh ciri ciri idhgam, tombol A-E ketika di klik berfungsi untuk beralih ke contoh-contoh idhgam nya.

\section{Halaman Pengenalan Huruf Huruf Hijaiyyah Beserta Pengertiannya} Gambar 1.3

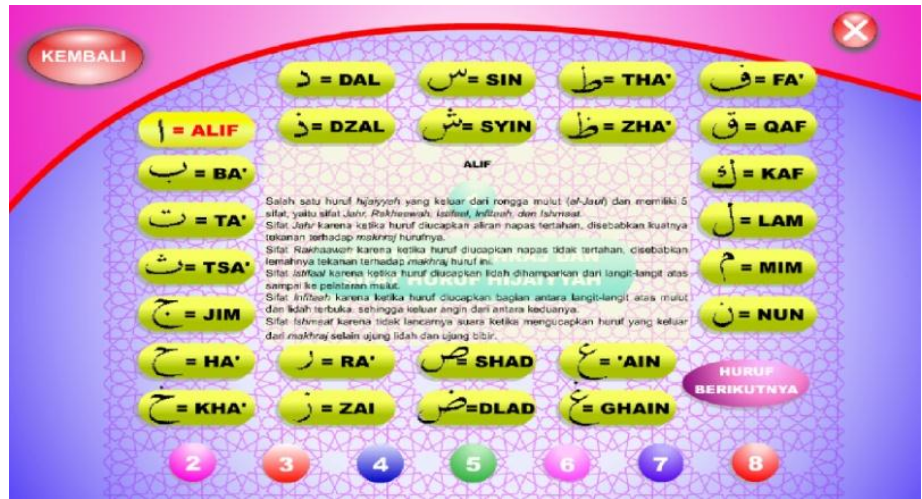

Gambar disamping merupakan hasil ketika user memilih tombol huruf hijaiyah pada menu 28 huruf hijaiyah yang beda konsonan sama dengan huruf latin. Halaman ini terdapat gambar letak keluar makhrojnya. Tampilan halaman 28 huruf hijaiyah dapat dilihat pada gambar disamping. Halaman ini merupakan hasil ketika user memilih tombol huruf hijaiyah pada menu Bentuk, Makhraj, dan Sifat huruf Hijaiyyah huruf hijaiyah berisi materi 28 huruf hijaiyah yang berkonsonan. Terdapat button merah disisi kiri atas untuk kembali ke menu. 


\section{Scene Flowchart Tajwid}

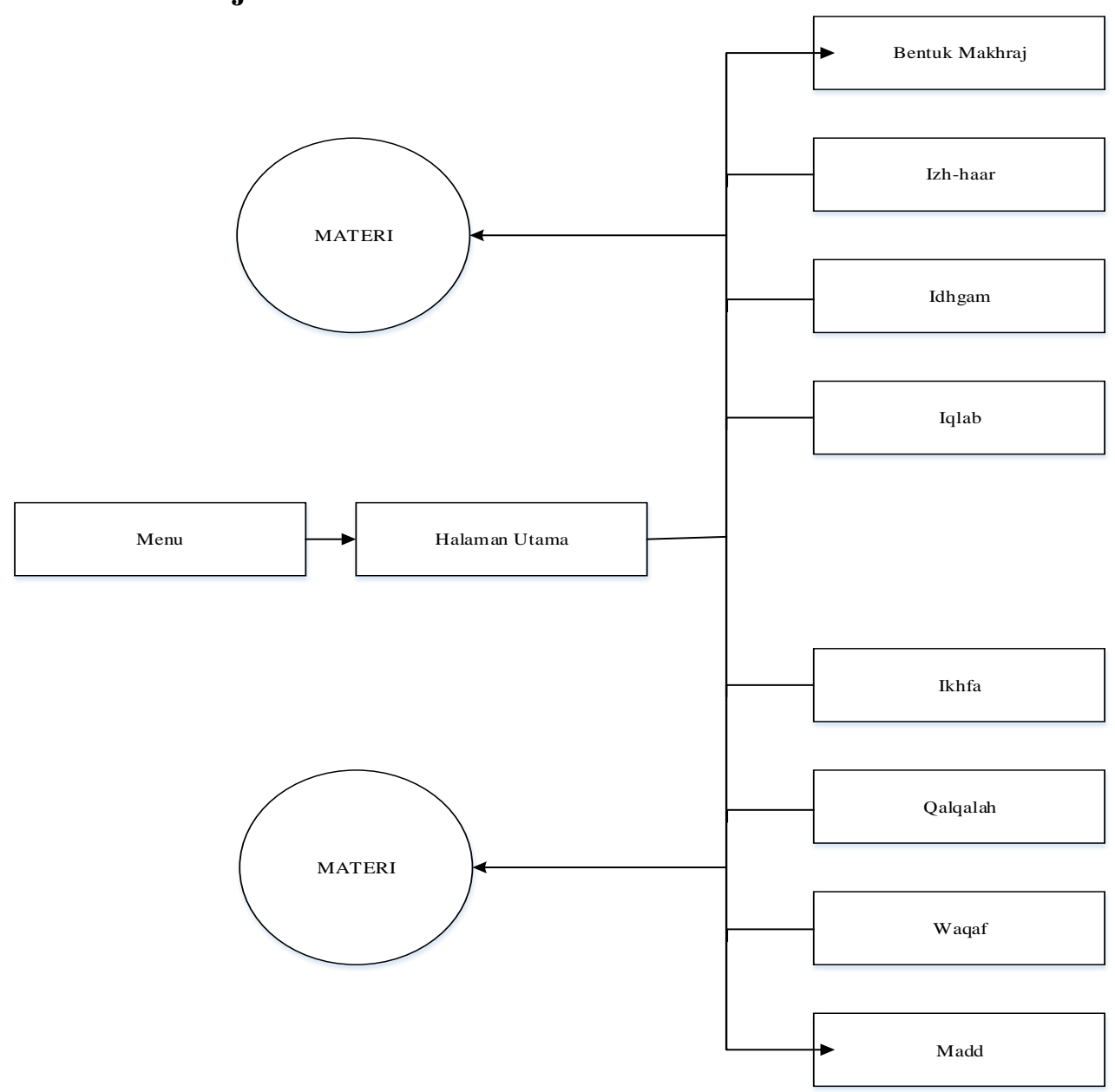

\section{Coding}

Tahap coding merupakan tahap pengkodean dari desain ke dalam suatu bahasa pemrograman. Dalam sistem ini desain telah dibuat dengan menggunakan Macromedia flash 8 .

\section{Pengujian (Testing )}

Tahap selanjutnya yaitu testing (Pengujian Sistem). Testing hanya menggunakan satu cara pengujian yaitu Blackbox Test. Pengujian dengan cara Blackbox test, yaitu pengujian sistem yang dilakukan dengan mengamati keluaran dari berbagai masukan. Jika keluaran sistem telah sesuai dengan rancangan untuk variasi data, maka system tersebut dinyatakan baik. Metode ujicoba blackbox digunakan sebagai kegian dalam keperluan fungsional dari aplikasi multimedia pengenalan Tajwid Berbasis. Ujicoba pada animasi ini agar dapat membuat kesimpulan, memungkinkan pengembang aniasi ini untuk membuat kondisi input yang akan melatih seluruh syarat-syarat fungsional suatu program animasi multimedia pengenalan tajwid berbasis flash.

Tabel 1. Pengujian

\begin{tabular}{|l|l|l|l|}
\hline \multicolumn{1}{|c|}{ Input/Event } & \multicolumn{1}{|c|}{ Proses } & \multicolumn{1}{c|}{ Output } & \multicolumn{1}{c|}{ Hasil } \\
\hline Menu Utama & $\begin{array}{l}\text { Terdapat } 8 \mathrm{Menu} \\
\text { Utama }\end{array}$ & $\begin{array}{l}\text { Tampil menu } \\
\text { utama }\end{array}$ & Sesuai \\
\hline
\end{tabular}




\begin{tabular}{|l|l|l|l|}
\hline File & $\begin{array}{l}\text { Terdapat sub dalam } \\
\text { menu }\end{array}$ & Tampil Sub & Sesuai \\
\hline User Memulai & $\begin{array}{l}\text { Jika ingin } \\
\text { memulai } \\
\text { menekan tombol } \\
\text { yang di kehendaki }\end{array}$ & Tampil & Sesuai \\
\hline Halaman Baca & $\begin{array}{l}\text { Jika ingin } \\
\text { memulai membaca } \\
\text { dapat langsung } \\
\text { menekan tombol } \\
\text { yang di pilih }\end{array}$ & $\begin{array}{l}\text { Tampil halaman } \\
\text { Jika ingin } \\
\text { mengakhiri } \\
\text { program ini dapat } \\
\text { langsung } \\
\text { menekan tombol } \\
\text { keluar }\end{array}$ & $\begin{array}{l}\text { Sesuai } \\
\text { tanda untuk } \\
\text { keluar } \\
\text { aplikasi }\end{array}$ \\
\hline Keluar & Sesuai \\
\hline
\end{tabular}

Pendapat responden digunakan untuk Ujicoba pada media ini agar dapat membuat kesimpulan untuk mengetahui persentase pengguna terhadap aplikasi multimedia pengenalan Tajwid. Apakah aplikasi ini sesuai atau tidak berdasarkan hasil responden dari 25 siswa SMP Hikmah Teladan. Indikator ini terdiri dari 10 pernyataan. Menurut Lase (2012) dalam penelitianya ada beberapa indikator penggunaan, Tingkat kebutuhan, Kecocokan, Motivasi, Kreatifitas, Kesesuaian, Ketertarikan, Kemudahan, Peminat, Kesulitan.

Tabel 3. Tabel Pernyataan Pernyataan siswa

\begin{tabular}{|l|l|c|c|}
\hline No & \multicolumn{1}{|c|}{ Pernyataan } & Y & T \\
\hline 1 & Tingkat kebutuhan pengguna & 20 & 5 \\
\hline 2 & Tingkat Kecocokan dengan pengguna & 25 & 0 \\
\hline 3 & Tingkat kemudahan Aplikasi & 25 & 0 \\
\hline 4 & Tingkat Motivasi pengguna & 24 & 1 \\
\hline 5 & Tingkat Kreatifitas pengguna & 23 & 2 \\
\hline 6 & Tingkat Kesesuaian dengan kondisi pengguna & 20 & 5 \\
\hline 7 & Tingkat Ketertarikan menggunakan aplikasi & 25 & 0 \\
\hline 8 & Tingkat Kemudahan menggunakan Aplikasi & 24 & 1 \\
\hline 9 & Tingkat Peminat menggunakan aplikasi & 25 & 0 \\
\hline 10 & Tingkat Kesulitan menggunakan aplikasi & 6 & 19 \\
\hline
\end{tabular}

\begin{tabular}{|l|l|c|c|}
\hline No & \multicolumn{1}{|c|}{ Pernyataan } & $\begin{array}{c}\text { Persentase } \\
\text { Ya }\end{array}$ & $\begin{array}{c}\text { Persentase } \\
\text { Tidak }\end{array}$ \\
\hline 1 & Tingkat kebutuhan pengguna & $80 \%$ & 5 \\
\hline 2 & Tingkat Kecocokan dengan pengguna & $100 \%$ & 0 \\
\hline
\end{tabular}




\begin{tabular}{|l|l|c|c|}
\hline 3 & Tingkat kemudahan Aplikasi & $100 \%$ & 0 \\
\hline 4 & Tingkat Motivasi pengguna & $96 \%$ & $4 \%$ \\
\hline 5 & Tingkat Kreatifitas pengguna & $92 \%$ & $8 \%$ \\
\hline 6 & Tingkat Kesesuaian dengan kondisi pengguna & $80 \%$ & $20 \%$ \\
\hline 7 & Tingkat Ketertarikan menggunakan aplikasi & $100 \%$ & 0 \\
\hline 8 & Tingkat Kemudahan menggunakan Aplikasi & $96 \%$ & $4 \%$ \\
\hline 9 & Tingkat Peminat menggunakan aplikasi & $100 \%$ & 0 \\
\hline 10 & Tingkat Kesulitan menggunakan aplikasi & $24 \%$ & $76 \%$ \\
\hline
\end{tabular}

\section{Gambar.3 Grafik Siswa}

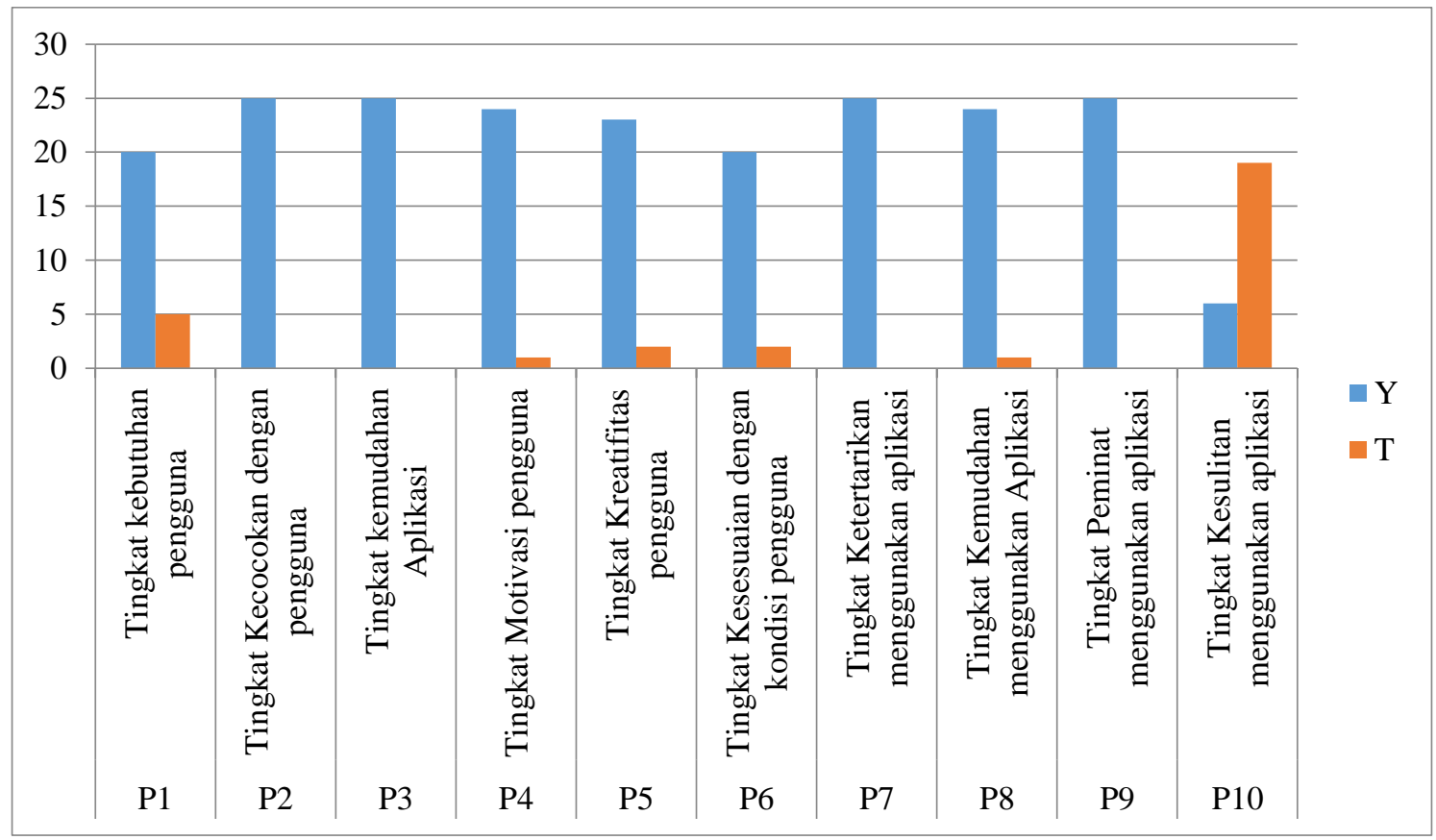

Berdasarkan tahap-tahap penelitian dan pengembangan yang telah dilalui serta dilaksanakan, bisa ditarik beberapa hasil sebagai berikut:

1. Hampir seluruh siswa memberikan responpositif mengenai pembelajaran yang menggunakan multimedia pembelajaran permainan, dalam konteks dapat membawa manfaat, menarik, dan mampu meningkatkan motivasi belajar siswa.

2. Ditinjau dari aspek umum, rekayasa perangkat lunak, komunikasi visual, substansi materi dan pembelajaran, maka pengenalan multimedia interaktif yang dihasilkan dikategorikan cukup baik.

3. Ditinjau dari aspek tombol navigasi, tampilan multimedia, kemudahan penggunaan multimedia dan interaktifitas multimedia, dinilai baik oleh hampir seluruh siswa.

4. Penggunaan media berbasis flash ini sangat mudah dan tidak diperlukan keahlian khusus untuk menjalankan oleh user sehingga dapat diakses mudah oleh siapa saja. 


\section{SIMPULAN}

Setelah penulis menganalisa dan menguraikan seluruh pembahasan dari penulisan penelitian yang sederhana ini mengenai pengenalan interaktif pembelajaran Ilmu Tajwid berbasis flash, maka penulis dapat menarik kesimpulan yaitu :

1. Metode pembelajaran aplikasi interaktif ini sangat bermanfaat karena dapat memudahkan siswa-siswi dalam memahami pembelajaran ilmu tajwid berbasis multimedia dan menimbulkan rasa senang serta memotivasi selama proses pembelajaran berlangsung. .

2. Dengan adanya aplikasi berbasis flash interaktif ini dapat membuat para pengajar agar selalu kreatif dan tercapai tujuan pembelajaran yang maksimal.

3. Dalam merancang multimedia pembelajaran dengan menggunakan visualisasi gambar harus lebih menarik, dan memasukkan efek suara akan membuat multimediapembelajaran yang disampaikan lebih interaktif untuk meningkatkan daya ingat atau daya tangkap pengguna.

Dari aplikasi interaktif yang telah dibuat mampumemberikan inovasi dalam pembelajaran, sehingga dengan perkembangan teknologi animasi interaktif saat ini diharapkan pengembangan sebagai berikut :

1. Aspek manajerial: Diharapkan semakin banyak perkembangan belajar mengajar menggunakan media komputer berbasis multimedia dan diadakan penyuluhan serta pelatihan mengenai cara belajar mengajar menggunakan media pembelajaran interaktif.

2. Aspek sistem/program: Diharapkan semakin mengembangkan kreatifitas dalam membuat objek atau gambar serta berikan efek warna dan cahaya, dengan maksud menghasilkan objek tampak lebih hidup dan bervariasi.

3. Aspek penelitian selanjutnya dikembangkan mengenal terlebih dahulu user atau pengguna yang akan menggunakan multimedia yang dibuat, sasaran dan tujuan pengguna multimedia harus tepat.

\section{DAFTAR PUSTAKA}

A.S, Sadiman. dkk. Media Pendidikan: Pengertian, Pengembangan, dan. Pemanfaatannya. Jakarta: PT.Raya Grafindo Persada, 1996

Ariesto Hadi, Sutopo. Multimedia Interaktif dan Flash. PT Graha Ilmu: Yogyakarta, 2003

Arsyad, Azhar. Media Pembelajaran. Jakarta : Raja Grafindo, 2011.

http://tonyjustinus.wordpress.com/2017/06/12/waterfall-process-model/. Diakses pada hari Senin, 22/01/2017 pukul 23.11 WIB.,

Justinus, Tony, Waterfall Process Model. 2007

Omar Hamalik, Perencanaan Pengajaran Berdasarkan Pendekatan Sistem, Jakarta : Bumi Aksara, 2002.

Pressman, Roger. S, Software Engineering: A Practioner's Approach. 4th . McGrawHill. 1997. 
Agus Taufik, Ari Kaharudin, Abdul Qodir

Raymond Simamora . Buku Ajar Pendidikan Dalam Keperawatan. Jakarta. Buku kedokteran EGC, 2009

Sudjana, Nana dan Ahmad Rivai. Media Pengajaran. Bandung: Sinar Baru, 2002

Tim Penyusun Kamus Pusat Bahasa, Kamus Besar Bahasa Indonesiai, Jakarta:Balai Pustaka, 2005.

Warsita, Bambang. Teknologi Pembelajaran: Landasan \&Aplikasinya, Jakarta: Rineka, 2008.

Wina Sanjaya, Strategi Pembelajaran, Kencana Prenada Group, 2008. 